\title{
INTERAKSI SOSIAL ANTAR ORANG KEI DI NEGERI PASSO KECAMATAN BAGUALA KOTA AMBON
}

\author{
Fransiska Rahabav, Tonjti Soumokil, Christwyn R. Alfons, Jouverd F. Frans \\ Program Studi Sosiologi Fakultas Ilmu Sosial dan Ilmu Politik \\ Universitas Pattimura \\ niarahabav@gmail.com, tontjisoumokil@gmail.com, alfonschristwyn@gmail.com,
}

\begin{abstract}
Abstrak
Penelitian ini merupakan penelitian deskriptif kualitatif yang bertujuan untuk mengetahui dan menjelaskan bentuk-bentuk interaksi sosial antar orang Kei di Negeri Passo Kecamatan Baguala Kota Ambon. Penelitian ini dilaksanakan di Negeri Passo Kecamatan Baguala Kota Ambon. Hasil penelitian menunjukkan bahwa orang Kei di Negeri Passo terdiri dari kasta Mel-Mel, Ren-Ren, Iriri. Namun dalam kehidupan sehari-hari, tidak tampak perbedaan kasta di antara mereka. Mereka hidup bersama atau berkelompok dengan perbedaan yang ada namun tidak pernah terjadi masalah. Hubungan interaksi sosial di antara mereka ketiga kasta terjalin dengan sangat baik sehingga tampak rukun dan aman. Bentukbentuk interaksi sosial yang tampak dalam kehidupan bersama orang Kei di Negeri Passo seperti, Yelim dan Maren. Yelim dan Maren merupakan dua tradisi yang mengandung makna saling membantu dan saling menolong satu sama lain. Yelim dan Maren merupakan dua bentuk interaksi sosial yang mewujudkan serta memperkuat rasa solidaritas sosial orang Kei di Negeri Passo. Penguatan rasa solidaritas sosial orang Kei di Negeri Passo juga disebabkan oleh falsafah hidup mereka yaitu Ain Ni Ain yang artinya rasa persaudaraan yang berasal dari leluhur yang sama, suku yang sama, bahasa yang sama, adat istiadat yang sama, dan tidak membeda-bedakan latar belakang agama, kelas sosial, ekonomi, dan lain-lain.
\end{abstract}

Kata Kunci: Interaksi Sosial, Kelas Sosial (Kasta), Solidaritas Sosial.

This research is a qualitative descriptive study that aims to determine and to explain the forms of social interaction between the Kei people in Negeri Passo, Baguala District of Ambon. The research was conducted in Passo Village, Baguala District Ambon of Maluku. Primary data collection was carried out through in-depth interviews with a number of informant who were considered to be directy involved in this study. The results showed that the Kei people in Negeri Passo consisted of the Mel-Mel, the RenRen, and the Iriri castes. But in daily life, there was no visible difference in caste between them. They lived together or in groups with differences, but there was never a problem. The social interaction relationship between these three castes was very well established so that it looked harmonious and safe. The forms of social interaction that appear in life with the Kei people in Negeri Passo such as; Yelim and Maren, are two traditions that contain the meaning of helping one another and realizing a sense of social solidarity of the Kei people in Negeri Passo. In addition, the strengthening of their sense of social solidarity is also caused by the philosophy of life "Ain Ni Ain" which means a sense of brotherhood that comes from the same ancestors, the same tribe, the same language, the same custome, and does not discriminate against religious backgrounds, social class, economy, ect.

Keywords: Social Interaction, Social Class (Caste), Social Solidarity. 


\section{Pendahuluan.}

Masyarakat Indonesia sejak jaman dahulu sudah dikenal sebagai masyarakat yang majemuk atau plural. Kemajemukan masyarakat Indonesia, salah satunya ditandai oleh adanya keanekaragaman suku bangsa yang hidup berbaur dan menyebar di seluruh pelosok nusantara. Keanekaragaman suku bangsa ini pula yang kemuidan menjadi salah satu karakteristik kemajemukan masyarakat Indonesia hingga saat ini. Kemajemukan tersebut juga tampak pada struktur masyarakat Indonesia yang terbagi secara horizontal dan vertikal, sebagaimana yang dikemukakan Nasikun (2009:34) bahwa struktur masyarakat Indonesia ditandai oleh dua cirinya yang bersifat unik. Secara horizontal, struktur masyarakat Indonesia ditandai oleh kenyataan adanya kesatuan-kesatuan sosial berdasarkan perbedaan-perbedaan suku bangsa, perbedaan-perbedaan agama, adat serta perbedaan-perbedaan kedaerahan. Secara vertikal, struktur masyarakat Indonesia ditandai oleh adanya perbedaan-perbedaan antara lapisan atas dan lapisan bawah yang cukup tajam.

Perbedaan-perbedaan suku bangsa, perbedaan-perbedaan agama, adat serta kedaerahan inilah yang seingkali disebut sebagai ciri masyarakat Indonesia yang bersifat majemuk, suatu istilah yang mula-mula sekali diperkenalkan oleh Furnivall untuk mengambarkan masyarakat Indonesia pada masa Hindia-Belanda. Masyarakat Indonesia pada masa Hindia-Belanda, demikian menurut Furnivall, merupakan suatu masyarakat majemuk (plural societies), yakni suatu masyarakat yang terdiri atas dua atau lebih elemen yang hidup sendiri-sendiri tanpa ada pembauran satu sama lain di dalam suatu kesatuan politik (Nasikun, 2009:35).

Dengan cara yang lebih singkat, Pierre L. van den Berghe (Nasikun, 2009:40-41) menyebutkan beberapa karakteristik sebagai sifat-sifat dasar dari suatu masyarakat majemuk, yaitu:(1). Terjadinya segmentasi ke dalam bentuk kelompok-kelompok yang seringkali memiliki subkebudayaan yang berbeda satu sama lain; (2). Memiliki struktur sosial yang terbagi-bagi ke dalam lembaga-lembaga yang bersifat nonkomplementer; (3). Kurang mengembangkan konsensus di antara para anggotanya terhadap nilai-nilai yang bersifat dasar; (4). Secara relatif seringkali mengalami konflik-konflik di antara kelompok yang satu dengan kelompok yang lain; (5). Secara relatif, integrasi sosial tumbuh di atas paksaan (coercion) dan saling ketergantungan di dalam bidang ekonomi; (6). Adanya dominasi politik oleh suatu kelompok atas kelompok-kelompok yang lain. 
Keberadaan masyarakat Indonesia yang majemuk berdasarkan perbedaan latar belakang identitas asal. Kemajemukan masyarakat Indonesia juga tampak pada struktur masyarakat yang terstratifikasi selain dalam bentuk lapisan atas dan lapisan bawah, juga dalam bentuk kasta yang tercipta karena sejarah perjalanan perkembangan masyarakat itu sendiri. Hal ini yang kemudian menyebabkan munculnya pengelompokan dalam masyarakat yang ditandai oleh adanya gejala dimana masyarakat mempunyai penghargaan tertentu terhadap hal-hal tertentu dalam masyarakat yang bersangkutan, yakni perbedaan posisi seseorang atau suatu kelompok dalam kehidupan yang berbedabeda secara vertikal atau lazim disebut stratifikasi sosial.

Stratifikasi sosial didefenisikan oleh Patirim A. Sorokin sebagai perbedaan penduduk atau masyarakat ke dalam kelas-kelas secara bertingkat. Perwujudan dari stratifikasi sosial adalah adanya kelas-kelas tinggi dan kelas yang lebih rendah di dalam masyarakat. Dasar dan inti lapisan-lapisan dalam masyarakat adalah tidak adanya keseimbangan dalam pembagian hak-hak dan kewajiban-kewajiban, kewajibankewajiban dan tanggung jawab nilai-nilai sosial dan pengaruhnya di antara anggotaanggota masyarakat (Basrowi, 2005:60).

Berdasarkan sifatnya, maka pada dasarnya stratifikasi sosial dalam masyarakat dapat dikelompokkan menjadi dua yaitu, stratifikasi sosial tertutup (closed social stratification) dan stratifikasi sosial terbuka (open social statification). Stratifikasi sosial tertutup, bercirikan sulitnya seseorang untuk berpindah darisatu lapisan ke lapisan lain sedangkan stratifikasi sosial terbuka bercirikan setiap anggota masyarakat mempunyai kesempatan untuk berpindah ke lapisan yang lain (yang lebih tinggi). Hal ini dapat dilakukan dengan usaha berdasar kecakapannya sendiri (Basrowi, 2005:61).

Sifat stratifiksi sosial tersebut sebagaimana yang tampak pula pada masyarakat Indonesia dimana terdapat masyarakat dengan sifat stratifikasi sosial tertutup dan juga stratifikasi sosial terbuka. Stratifikasi sosial tertutup di Indonesia seperti yang tampak pada masyarakat Bali dan masyarakat Kepulauan Kei di Maluku. Pada kedua kelompok masyarakat ini berlaku sistem kasta yang sudah ada sejak leluhur mereka dan hingga sekarang masih tetap diakui serta dilestarikan dalam kehidupan sehari-hari.

Masyarakat Kepulauan Kei atau yang biasa disebut orang Kei merupakan suatu kelompok masyarakat majemuk yang terstruktur secara horizontal dan vertikal. Struktur masyarakat Kepulauan Kei atau orang Kei tersebut secara horizontal tampak pada adanya perbedaan-perbedaan sub suku, agama dan juga kewilayahan. Sedangkan secara vertikal 
tampak pada adanya perbedaan antara lapisan atas dan lapisan bawah yang hingga kini masih terus dipertahankan.

Dalam kehidupan orang Kei hampir tidak memiliki catatan sejarah tertulis. Mereka hanya memiliki tom - tad, yakni hikayat-hikayat lisan yang disertai dengan bendabenda warisan tertentu sebagai penjamin keoutentikan hikayat itu. Sebagian besar hikayat itu dibumbui dongeng atau lambang-lambang yang keberadaannya dianggap benar secara harafiah oleh orang Kei pada umumnya. Dari beberapa catatan sejarah disebutkan bahwa orang Kei berasal dari berbagai daerah di tanah air Indonesia, yakni dari daerah bagian barat seperti Pulau Jawa, Pulau Bali, dan Nusa Tenggara sedangkan juga dari daerah bagian timur seperti Maluku Utara, Ternate, Tidore, Jailolo dan Maluku Tengah, Pulau Ambon, Seram, Banda, Watebula, Luang Leti, Aru, serta Irian (Papua).

Berdasarkan asal usul tersebut, maka dalam kehidupan orang Kei kemudian muncul pengelompokan masyarakat yang biasa mereka sebut kasta atau yang lebih dikenal dengan sebutan kelas sosial. Dengan demikian pada orang Kei dijumpai 3 (tiga) kelas sosial yang sudah diakui sejak dahulu hingga sekarang. Ketiga kelas sosial tersebut yaitu;

1. Mel-mel (Kelas Bangsawan), mereka adalah kaum pendatang yang cerdik, pandai, berani dan kaya.

2. Ren-ren (Kelas Menengah), mereka adalah penduduk asli dan kurang pandai.

3. Iriri (Kelas Bawah), mereka adalah orang-orang yang sebab salahnya ditebus dan menjadi hamba disebut iri-iri tivtivut (hamba yang ditebus) atau orang yang dibeli dengan sengaja untuk menjadi hamba atau disebut juga iriri emas enen (harga emas, hamba yang dibeli) (Ohoitimur, 1983:13).

Kelas-kelas sosial yang terdapat pada orang Kei hingga kini masih tetap terpelihara dan diakui keberadaannya sehingga menjadi salah satu faktor pembeda dalam kehidupan bersama mereka. Dalam kehidupan sehari-hari terutama di Kepulauan Kei, perbedaan kelas sosial menjadi faktor yang menghambat pola-pola interaksi sosial antar warga. Hal ini karena masing-masing kelas sosial menyadari akan statusnya sehingga mereka lebih cenderung melakukan interaksi antara sesama anggota kelas daripada dengan anggota kelas sosial yang lain. Namun apabila terjadi interaksi antar kelas sosial, misalnya kelas sosial atas (Mel-Mel) dengan kelas sosial bawah (Iriri) maka pola hubungan tersebut lebih bersifat ketaatan. Artinya bahwa pola ketaatan ini terjadi antara kelas Mel-Mel sebagai kelompok superordinasi dan kelas Iriri sebagai kelompok 
subordinasi. Kelas Iriri sebagai kelompok subordinasi selalu menyadari diri serta posisi mereka di antara kelas $\mathrm{Mel}-\mathrm{Mel}$ dan Ren-Ren dalam kehidupan sehari-hari sehingga sulit bagi terciptanya pola-pola interaksi yang intensif guna tercapainya suasana hidup yang harmonis.

Dalam pola hubungan superordinasi (dominasi) dan subordinasi (ketaatan) yang tampak pada kehidupan orang Kei di Kepulauan Kei, George Simmel (Ritzer dan Goodman, 2008:177-178), beranggapan bahwa beragam bentuk interaksi merupakan kemampuan aktor untuk menciptakan struktur sosial, maupun efek merusak dari strukturstruktur tersebut tersebut terhadap kreatifitas individu. Bentuk interaksi menunjukkan bahwa aktor mengorientasikan diri secara sadar kepada sesamanya. Jadi, misalnya interaksi dalam sistem terstratifikasi mengharuskan superordinasi dan subordinasi mengorientasikan diri satu sama lain. Interaksi ini akan sirna dan sistem stratifikasi akan runtuh jika proses orientasi timbal balik tidak terjadi.

Pola hubungan warga masyarakat yang terstratifikasi seperti tampak pada orang Kei, tentu akan sangat sulit untuk tercapainya solidaritas sosial. Hal ini karena perbedaan kelas-kelas sosial yang ada pada orang Kei lebih menuntut mereka untuk saling berinteraksi dalam sistem kelasnya masing-masing daripada antar kelas sehingga yang tampak adalah solidaritas ingroup pada masing-masing kelas sosial lebih kuat daripada solidaritas orang Kei secara keseluruhan. Solidaritas orang Kei dapat terwujud secara utuh atau keseluruhan apabila kelas atas (Mel-Mel dan Ren-Ren sebagai superordinasi) memiliki kepentingan dan kebutuhan yang harus dicapai sehingga kelas Iriri (sebagai subordinasi) wajib mendukung pemenuhan kepentingan dan kebutuhan tersebut. Bentuk solidaritas sosial yang demikian menunjukkan adanya suatu pengaruh dominasi kelas $\mathrm{Mel}$ Mel dan Ren-Ren terhadap kelas Iriri. Namun dibalik pola hubungan atau interaksi sosial yang demikian, pada orang Kei terdapat kebiasaan-kebiasaan yang dapat meciptakan dan memperkuat solidaritas sosial antara ketiga kelas sosial tersebut, seperti diantaranya kebiasaan tolong-menolong pada suatu acara kedukaan (kematian), dan kebiasaan selalu bersatu apabila ada salah seorang dari mereka yang mengalami masalah (misalnya, ada orang Kei dipukul oleh warga lain) maka secara bersama mereka akan bersatu untuk melawan balik. Hal ini yang menjadi kebiasaan-kebiasaan yang sudah melekat dalam diri semua orang Kei tanpa memandang perbedaan kelas sosial.

Melalui suatu pengamatan awal terhadap Orang Kei di Negeri Passo ternyata ditemukan adanya kebiasaan-kebiasaan yang seperti disebutkan di atas. Misalnya, pada 
suatu acara kedukaan (kematian) yang dialami oleh salah satu keluarga orang Kei di Negeri Passo, ternyata banyak orang Kei lainnya datang berkunjung serta membawa bantuan berupa sumbangan dalam bentuk barang-barang kebutuhan pokok seperti diantaranya beras, gula, atau bahkan uang. Hal ini merupakan suatu kebiasaan yang berlaku umum dan tidak membeda-bedakan kelas sosial, artinya apabila seseorang dari keluarga orang Kei yang meninggal maka semua orang Kei wajib membantu keluarga yang berduka. Kebiasaan seperti ini menunjukkan begitu kuatnya solidaritas sosial yang muncul dalam kehidupan bersama orang Kei di Negeri Passo.

Durkheim (Jhonson, 1986:181) menyatakan bahwa solidaritas secara sederhana menunjuk pada satu keadaan hubungan antara individu dan/atau kelompok yang didasarkan pada perasaan moral dan kepercayaan yang dianut bersama yang diperkuat oleh pengalaman emosional bersama.

Bentuk solidaritas sosial yang tampak pada orang Kei di Negeri Passo saat ini juga menunjukkan bahwa, walaupun mereka ada dalam kelas-kelas sosial namun tidak menjadi penghambat interaksi sosial antara satu dengan yang lain. Proses interaksi sosial di antara mereka terjalin dengan sangat baik tanpa ada rasa perbedaan satu sama lain. Mereka hidup bersama, saling menolong, saling mendukung satu sama lain dengan perasaan kebersamaan yang menjadi dasar terciptanya solidaritas sosial.

Permasalahan yang dapat dikemukakan adalah bagaimana bentuk-bentuk interaksi sosial antar orang Kei di Negeri Passo Kecamatan Baguala Kota Ambon. Tujuan dari penelitian ini adalah 1) untuk mengetahui bagaimana bentuk-bentuk interaksi sosial antara orang Kei di Negeri Passo Kecamatan Baguala Kota Ambon. 2) Untuk mendeskripsikan bentuk-bentuk interaksi sosial antar orang Kei di Negeri Passo Kecamatan Baguala Kota Ambon.

\section{Metode Penelitian.}

Metode yang digunakan dalam penelitian ini adalah metode penelitian kualitatif. Bogdan dan Taylor (Moleong, 2005:4) menyatakan bahwa metodologi kualitatif sebagai prosedur penelitian yang menghasilkan data deskriptif berupa kata-kata tertulis atau lisan dari orang-orang dan perilaku yang dapat diamati. Demikian maka, dengan menggunakan metode penelitiian kualitatif, peneliti dapat mendeskripsikan bentuk-bentuk interaksi sosial antar orang Kei di Negeri Passo Kecamatan Baguala Kota Ambon. 
Penelitian dengan judul interaksi sosial antar orang Kei di Negeri Passo Kecamatan Baguala Kota Ambon. Pemilihan Negeri Passo sebagai lokasi penelitian karena di Negeri Passo, terdapat begitu banyak orang Kei yang telah menjalani kehidupan bersama sejak lama dan hingga kini tetap ada menjadi bagian dari masyarakat Passo.

Dalam melakukan pengumpulan data, peneliti menggunakan beberapa instrumen penelitian seperti pedoman wawancara, alat foto (camera digital), alat perekam (tape recorder), dan alat tulis-menulis (buku notes dan pena).

Teknik pengumpulan data dalam penelitian kualitatif dilakukan melalui pengamatan (observasi) dan wawancara mendalam (Indepth Interview). Sebelum melakukan kegiatan pengumpulan data lapangan melalui wawancara mendalam dengan para informan, peneliti telah melakukan pengamatan di lapangan, khususnya pada lokasi penelitian yaitu di Negeri Passo. Dari hasil pengamatan di lokasi penelitian, peneliti menemukan bahwa orang Kei di Negeri Passo menjalani kehidupan secara bersama atau berkelompok. Mereka hidup bersama dengan rumah-rumah yang saling berdekatan satu dengan yang lain, adapun hanya dipisahkan oleh jalan setapak yang perkiraan ukuran lebarnya mungkin tidak cukup 1 meter.

Setelah melakukan 2 kali observasi lapangan pada hari yang berbeda, peneliti kemudian melakukan pengumpulan data melalui kegiatan wawancara mendalam kepada para informan yang telah ditentukan. Kegiatan ini berjalan dengan baik, walau kadang peneliti juga mengalami kendala karena ada informan yang ragu-ragu untuk bertemu dengan peneliti karena situasi Virus Corona (COVID-19) yang sementara mewabah. Namun, situasi tersebut dapat peneliti lewati dengan baik karena melalui pendekatan kepada tokoh masyarakat dan tokoh agama, khususnya orang Kei yang ada di sekitar lokasi penelitian dan sekaligus mereka merupakan bagian dari informan yang akan peneliti wawancarai. Demikian secara singkat gambaran kegiatan observasi dan pengumpulan data melalui wawancara mendalam yang peneliti lakukan terhadap orang Kei di Negeri Passo.

Dalam penelitian ini, informan yang ditetapkan oleh peneliti adalah sebagai berikut:, (1) Tokoh masyarakat Kei 2 orang, (2) Tokoh agama 1 orang, (3) Orang Kei dari kelas Mel-Mel 3 orang, (4) Orang Kei dari kelas Ren-Ren 3 orang, (5) Orang Kei dari Kelas Iriri 3 orang. Informan yang telah ditentukan dalam penelitian ini adalah sebanyak 12 orang yang kemudian ditetapkan sebagai informan kunci. 
Guna menganalisis data hasil penelitian, peneliti menggunakan analisis data kualitatif yang dikemukakan oleh Miles dan Huberman. Menurut Miles dan Huberman (2007:16-17), proses analisis data kualitatif berlangsung melalui tiga alur kegiatan yang terjadi secara bersamaan yaitu, reduksi data, penyajian data, penarikan kesimpulan atau verifikasi.

\section{Temuan dan Pembahasan.}

Secara administratif, Negeri Passo termasuk dalam wilayah Kecamatan Teluk Ambon Baguala Kota Ambon. Luas wilayah Negeri Passo adalah 35,17 Km², luas wilayah tersebut terbagi pada luas wilayah daratan $29,17 \mathrm{Km}^{2}$ dan luas wilayah laut $6 \mathrm{Km}^{2}$, sedangkan luas kawasan pemukiman penduduk adalah $120 \mathrm{Ha}$, yang menyebar pada 13 Rukun Warga (RW) yang membawahi 63 Rukun Tetangga (RT) dengan posisi garis pantai sepanjang 3,5 Km. Negeri Passo memiliki batas-batas wilayah sebagai berikut, Sebelah Utara, Berbatasan dengan Negeri Lama Teluk Ambon Baguala serta petuanan Negeri Hitu dan Negeri Mamala di Kecamatan Leihitu. Sebelah Selatan, Berbatasan dengan Teluk Baguala dan petuanan Negeri Hutumuri Kecamatan Leitimur Selatan. Sebelah Barat, Berbatasan dengan Kelurahan Lateri dan petuanan Negeri Halong Kecamatan Teluk Ambon Baguala. Sebelah Timur, Berbatasan dengan petuanan Negeri Suli Kecamatan Salahutu.

Jumlah penduduk Negeri Passo sebanyak 20.309 jiwa, dengan komposisi terdiri dari jumlah penduduk laki-laki sebanyak 10.059 jiwa dan jumlah penduduk perempuan sebanyak 10.250 jiwa. Jumlah Kepala Keluarga (KK) sebanyak 4.914 KK. Komposisi jumlah penduduk sesuai usia terdiri dari 0-11 bulan sebanyak 375 jiwa, 1-5 tahun sebanyak 1618 jiwa, 6-12 tahun sebanyak 2.366 jiwa, 13-15 tahun sebanyak 1.682 jiwa, 16-44 tahun sebanyak 14.691 jiwa, 45-59 tahun sebanyak 2710 jiwa, $\geq 60$ tahun sebanyak 1.259 jiwa. Berdasarkan penelitian tentang Interaksi Sosial Antar Orang Kei di Negeri Passo Kecamatan Baguala Kota Ambon maka dapat dijelaskan sebagai berikut:

\subsection{Hidup Bersama Dalam Perbedaan.}

Orang Kei di Negeri Passo sejak dahulu hingga sekarang selalu hidup rukun satu dengan yang lain. Mereka menjalin kehidupan bersama dengan saling menolong dan saling mendukung tanpa dihalangi perasaan-perasaan perbedaan yang ada. Perbedaan kasta atau strata sosia merupakan sejarah kebudayaan yang dimiliki dan sudah menjadi bagian kehidupan mereka yang tidak mungkin dilupakan tetapi harus terus dilestarikan 
dari generasi ke generasi. Setiap orang Kei, baik yang Mel-mel, Ren-ren, dan Iriri menyadari serta mengakui posisi mereka masing-masing dalam kehidupan bersama, tetapi kesadaran serta pengakuan itu tidak menjadi penghalang untuk mereka tetap dapat berinteraksi atau menjalin komunikasi satu sama yang lain dengan rukun. Kerukunan dalam hidup bersama dengan dasar kuatnya jalinan interaksi sosial ini sebenarnya didukung pula oleh adanya pesan-pesan atau amanah para leluhur yang hingga kini masih selalu diingat serta dilaksanakan.

Pesan-pesan atau amanah tersebut yang apabila diucapkan dalam bahasa daerah (bahasa Kei) berbunyi; “Manut Ain Mehe Ni Tilur, Vu'ut Ain Mehe Ni Ngivun” yang apabila diartikan dalam bahasa Indonesia adalah "Ayam punya satu telur dan Ikan punya satu ingsang yang dalam pengertian bahwa biar berbeda-beda tetapi kita tetap satu dari daerah yang sama dan bahasa yang sama”. Apabila pesan para leluhur ini dilihat dalam kehidupan sehari-hari orang Kei di Negeri Passo maka dapat dikatakan memiliki makna penting. Artinya bahwa walaupun mereka berbeda namun dengan selalu teringat akan pesan para leluhur maka perbedaan itu tidak menjadi halangan atau masalah yang dapat menghancurkan kehidupan bersama dengan rukun. Dengan kesadaran diri sebagai orangorang yang berasal dari daerah yang sama, bahasa yang sama, bahkan kebudayaan yang sama serta interaksi sosial yang selalu terwujud melalui rasa saling tolong-menolong satu dengan yang lain telah menjadi kekuatan bagi terwujudnya solidaritas sosial dalam kehidupan mereka. Hal ini pun tidak terlepas dari kuatnya pengaruh hukum Larvul Ngabal yang selalu dipegang teguh dan menjadi pedoman hidup setiap orang Kei untuk bersikap serta berperilaku dalam mejalani kehidupan bersama, baik dengan sesama orang Kei atau dengan orang lain. Menjalani kehidupan bersama walaupun dalam perbedaan sudah menjadi kenyatan hidup semua masyarakat, begitu juga dengan orang Kei di Negeri Passo. Orang Kei di Negeri Passo dalam kenyataannya mereka berbeda sesuai dengan strata sosial yang telah menjadi tradisi atau adat istiadat yang tidak mungkin dilupakan. Namun pada kenyataannya juga, walaupun mereka berbeda, tidak menjadi suatu masalah yang menghalangi kehidupan bersama. Hal ini karena orang Kei memiliki hukum adat yang menjadi pedoman hidup dan mampu menuntun mereka untuk dapat menjalani kehidupan bersama dengan harmonis.

\subsection{Bentuk-Bentuk Interaksi Sosial Orang Kei.}

Kehidupan saling tolong menolong, saling membantu, dan menghormati satu dengan yang lain seakan telah menjadi tradisi hidup orang Kei. Hal ini juga tampak pada 
mereka yang ada di Negeri Passo. Orang Kei di Negeri Passo, selama ini menjalani kehidupan bersama dengan aman dan rukun. Mereka hidup bersama dengan saling tolong menolong, membantu dan menghormati satu dengan yang lain. Kehidupan saling tolong menolong, membantu, dan saling menghormati ini tampak ketika salah satu keluarga akan membangun rumah maka keluarga-keluarga yang lain tentu akan datang menolong bekerja bersama untuk mempercepat proses pembangunan. Tradisi tolong menolong ini kalau dalam bahasa Kei disebut Maren ${ }^{1}$. Menurut Ajawaila (2005), tradisi tolong menolong adalah suatu bentuk hubungan sosial yang telah lama dipraktekkan dalam kehidupan masyarakat tradisional. Budaya ini muncul karena adanya pemahaman bahwa anggota masyarakat yang berbeda pada suatu kesatuan tempat, desa, kampung, negeri adalah bagian dari keseluruhan masyarakat sebagai suatu totalitas.

Apabila seseorang akan melakukan suatu aktivitas, warga kampung akan secara langsung menyumbangkan tenaga dan harta benda untuk membantu orang tersebut. Selain maren, ada juga suatu tradisi yang menunjukkan kerukunan hidup orang Kei, khususnya yang ada di Negeri Passo. Tradisi yang dimaksud adalah tradisi saling membantu baik, dalam keadaan senang maupun keadaan susah, atau dalah bahasa Kei disebut Yelim $^{2}$ dan Yelim Matmatan ${ }^{3}$. Tradisi ini hingga kini masih terus dilakukan dalam kehidupan bersama orang Kei. Memberi bantuan kepada keluarga yang sedang melaksanakan acara dianggap sebagai bentuk kepedulian terhadap sesama keluarga sekaligus untuk meringankan beban keluarga tersebut. Hal yang sama juga seperti Yelim Matmatan, dimana bantuan diberikan kepada keluarga yang berduka sebagai wujud kepedulian dan rasa berduka serta sekaligus untuk meringankan beban keluarga yang berduka tersebut.

Tradisi memberikan bantuan kepada keluarga yang berduka atau disebut Yelim Matmatan merupakan salah satu bentuk hubungan-hubungan sosial dalam kehidupan orang Kei. Begitu juga dengan Yelim dan juga Maren, merupakan dua tradisi dalam kehidupan orang Kei yang menunjukkan bentuk-bentuk hubungan sosial atau interaksi sosial. Bentuk-bentuk hubungan sosial sebagaimana yang tampak dalam kehidupan orang Kei telah menjadi salah satu perekat yang menciptakan solidaritas sosial antar orang Kei yang berbeda kasta. Namun hubungan-hubungan sosial ini bukan terjadi tanpa norma

\footnotetext{
${ }^{1}$ Maren merupakan tradisi tolong menolong yang dilakukan dalam berbagai aktivitas. Misalnya membangun rumah, membuka lahan baru untuk kebun, dan kegiatan lainnya (Ajawaila,2005)

${ }^{2}$ Tradisi pemberian bantuan (beras, gula, uang, dll) kepada keluarga yang sedang melaksanakan acara, seperti pernikahan, peneguhan anggota sidi gereja unuk umat Kristen Protestan, dll.

${ }^{3}$ Tradisi pemberian bantuan (beras, gula, uang, dll) kepada keluarga yang sedang berduka (meninggal dunia).
} 
sosial yang mengikatnya karena peran norma sosia untuk menjaga supaya hubunganhubungan sosial itu tetap terlaksana dengan baik. Hubungan-hubungan sosial orang Kei dalam bentuk Yelim, Yelim Matmatan dan Maren diikat oleh norma sosial sehingga apabila ada keluarga yang tidak menjalankannya maka pasti akan mendapatkan sanksi sosial. Misalnya saja, apabila ada salah satu keluarga yang melaksanakan acara di rumahnya atau sedang berduka karena salah seorang anggota keluarganya meninggal dunia maka tentu keluarga-keluarga yang lain akan datang membantu dan memberikan bantuan, kalau ada yang tidak datang membantu atau memberikan bantuan maka pasti keluarga tersebut akan merasa malu atau suatu saat ketika keluarga ini melaksanakan acara atau berduka maka pasti tidak ada keluarga yang tidak memberikan bantuan. Hal ini merupakan wujud dari adanya norma sosial yang terlaksana dengan munculnya sanksi sosial dalam hubungan-hubungan sosial orang Kei.

Dalam kehidupan orang Kei, Yelim atau Yelim Matmatan dan Maren sudah menjadi tradisi turun-temurun yang diwariskan oleh para leluhur. Memberikan bantuan atau Yelim, Yelim Matmatan dan Maren juga dapat dikatakan sebagai salah satu wujud solidaritas yang menunjukkan perasaan susah dan senang secara bersama. Istilah yang lazim digunakan oleh orang Maluku yaitu "Satu Susah Semua Susah, Satu Senang Semua Senang" atau lebih sederhananya, "Susah Senang Sama-Sama". Istilah seperti ini yang kemudian selalu diingat dan dilaksanakan dalam kehidupan sehari-hari orang Kei, khususnya di Negeri Passo.

Terkait dengan solidaritas sosial orang Kei sebagaimana dijelaskan di atas maka, Johnson (1986:181) menyebutkan bahwa, solidaritas menunjuk pada satu keadaan hubungan antara individu dan/atau kelompok yang didasarkan pada perasaan moral dan kepercayaan yang dianut bersama yang diperkuat oleh pengalaman emosional bersama.

Orang Kei di Negeri Passo menjalani kehidupan bersama dengan rukun, walaupun seringkali muncul masalah, dianggap sebagai kesalahpahaman antar keluarga atau masalah pergaulan anak-anak dan semua masalah ini dapat segera diselesaikan secara kekeluargaan sehingga tidak menimbulkan konflik sosial. Kerukunan hidup orang Kei di Negeri Passo tentu tidak terlepas dari adanya hubungan-hubungan sosial di antara mereka yang selalu terjalin dengan baik. Hal ini tentunya juga didasarkan oleh adanya perasaan moral dan pengalaman emosional yakni mereka merasa berasal dari satu daerah serta memiliki bahasa yang sama atau dalam istilah orang Kei disebut "Manut Ain Mehe Ni 
Tilur, Vu'ut Ain Mehe Ni Ngivun" yang apabila diartikan dalam bahasa Indonesia adalah "Ayam punya satu telur dan Ikan punya satu ingsang yang dalam pengertian bahwa biar berbeda-beda tetapi kita tetap satu dari daerah yang sama dan bahasa yang sama” isitilah ini yang menunjukkan solidaritas sosial dan selalu menjadi pedoman hidup orang Kei di mana saja mereka ada dan menjalani kehidupan sosialnya.

\subsection{Berbeda Tidak Harus Terpisah.}

Orang Kei memiliki kasta atau strata sosial. Keberadaan kasta atau strata sosial ini sudah ada sejak dahulu sejak jaman leluhur. Namun keberadaan kasta itu tidak menjadi penghalang untuk orang Kei, khususnya di Negeri Passo menjalani kehidupan bersama. Orang Kei di Negeri Passo saat ini semuanya menjalani kehidupan sehari-hari secara bersama tanpa ada yang merasa berbeda. Mereka hidup rukun satu sama lain dan bahkan hubungan-hubungan sosial di antara mereka terjalin dengan baik pula. Sebagai orang Kei, masing-masing mereka menyadari bahwa mereka memiliki kasta, baik itu yang $\mathrm{Me}-\mathrm{Mel}$, Ren-Ren maupun Iriri. Namun dalam kehidupan sehari-hari, aktivitas sosial mereka jalani secara bersama tanpa masalah apapun.

Hubungan-hubungan sosial di antara mereka terjalin dengan baik, seperti salah satu contoh yang dapat disampaikan di sini bahwa pada setiap perayaan hari Natal yang merupakan hari raya umat Kristiani, mereka saling kunjung mengunjungi satu sama lain. Hal ini sudah menjadi sebuah tradisi yang senantiasa dilakukan setiap tahunnya. Tradisi kunjung mengunjungi ini menjadi salah satu bukti nyata yang mendasari terwujudnya kehidupan bersama atau solidaritas sosial orang Kei, khususnya di Negeri Passo. Menjalani kehidupan bersama atau berkelompok seakan sudah menjadi sebuah tradisi bagi orang Kei. Hal ini karena, di mana-mana pasti akan ditemukan orang Kei yang hidupnya berkelompok, seperti halnya yang tampak di Negeri Passo saat ini. Orang Kei di Negeri Passo, menjalani kehidupan bersama atau berkelompok. Mereka sudah lama menjalani kehidupan bersama atau berkelompok karena salah satu tujuannya adalah supaya saling membantu, saling menolong satu sama lain.

Hidup bersama atau berkelompok yang dijalani oleh orang Kei di Negeri Passo diakui sebagai sebuah tradisi atau pola hidup yang sudah lama ada. Walaupun mereka masing-masing menyadari akan adanya perbedaan kasta namun tidak menjadi masalah untuk menjalani kehidupan bersama atau berkelompok. Hal ini karena di antara mereka ada rasa saling menghormati satu sama lain di antara kasta. Rasa saling menghormati satu sama lain telah menjadi salah satu faktor yang mendorong terwujudnya tradisi hidup 
bersama atau berkelompok yang dijalani oleh orang Kei, khususnya yang ada di Negeri Passo saat ini.

Strata sosial atau kasta yang dimiliki setiap orang Kei saat ini, diakui juga sebagai warisan sejarah yang harus dijaga dan dilestarikan. Bagi setiap orang Kei, khususnya mereka yang ada di Negeri Passo, kasta yang melekat pada diri mereka saat ini sudah ada sejak mereka dilahirkan. Sejak seseorang itu dilahirkan maka dia sudah termasuk dalam kasta yang dimiliki oleh orangtuanya, baik itu Mel-Mel, Ren-Ren, atau Iriri sehingga keberadaan seseorang dengan kasta yang dimiliki adalah absolut. Artinya bahwa, seseorang yang terlahir dari orangtua yang memiliki kasta $\mathrm{Mel}-\mathrm{Mel}$ maka pada dirinya pun melekat kasta tersebut. Begitu juga dengan seseorang yang terlahir dari orangtua yang memiliki kasta Ren-Ren atau Iriri. Demikian pula, seseorang yang berasal dari kasta MelMel tidak dapat berpindah ke kasta Ren-Ren atau Irir, sebaliknya juga seseorang dari kasta Ren-Ren atau Iriri tidak dapat berpindah ke kasta Mel-Mel sekalipun mereka memiliki jabatan dan kekayaan.

Apabila strata sosial atau kasta yang berlaku di kehidupan orang Kei ini dilihat dari perspektif sosiologi maka termasuk dalam sifat stratifikasi sosial tertutup (closed social stratification). Stratifikasi sosial tertutup, bercirikan sulitnya seseorang untuk berpindah dari satu lapisan ke lapisan lain. Patirim A. Sorokin (dalam Basrowi, 2005) menyebutkan bahwa stratifikasi sosial merupakan pembedaan penduduk atau masyarakat ke dalam kelas-kelas secara bertingkat. Perwujudan dari stratifikasi sosial adalah adanya kelas-kelas tinggi dan kelas yang lebih rendah di dalam masyarakat.

Demikian maka dapat dikatakan bahwa, strata sosial atau kasta yang terdapat dalam kehidupan orang Kei merupakan salah satu sifat dari stratifikasi sosial yaitu stratifikasi sosial tertutup (closed social stratification). Wujud dari sifat stratifikasi sosial ini adalah seperti yang telah dijelaskan bahwa sulitnya seseorang yang berasal dari kasta Mel-Mel untuk dapat berpindah ke kasta Ren-Ren atau Iriri, sebaliknya juga seseorang dari kasta Ren-Ren atau Iriri tidak mungkin berpindah ke kasta $\mathrm{Mel}$-Mel sekalipun mereka memiliki jabatan dan kekayaan. Hal ini merupakan sebuah realita sosial yang tampak dalam kehidupan orang Kei, khususnya yang ada di Negeri Passo. Namun, walau dengan perbedaan kasta yang ada, tidak menghambat proses kehidupan sosial yang mereka jalani, karena selama ini mereka hidup dengan rukun dan aman. Dalam menjalani kehidupan sosialnya, orang Kei di Negeri Passo memang berbeda kasta tetapi mereka tidak terpisah, selalu hidup bersama atau berkelompok. 


\subsection{Falsafah Hidup Pembentuk Solidaritas Sosial.}

Orang Kei di Negeri Passo sangat menjunjung budaya dan falsafah hidup yang merupakan warisan para leluhur. Orang Kei memiliki budaya dan falsafah hidup yang sangat kuat, sehingga mengikat rasa persaudaraan di antara sesama mereka. Ain Ni Ain, merupakan falsafah hidup orang Kei yang selalu di ingat dan laksanakan di mana saja mereka merantau. Ain Ni Ain menurut orang Kei adalah rasa persaudaraan yang berasal dari leluhur yang sama, suku yang sama, bahasa yang sama, adat istiadat yang sama, dan tidak membeda-bedakan latar belakang agama, kelas sosial, ekonomi, dan lain-lain.

Makna yang tersirat dalam falsafah hidup Ain Ni Ain yang menjadi pedoman hidup orang Kei adalah, terdapat suatu perasaan persaudaraan yang kuat karena diikat oleh kesamaan identitas asal yaitu, berasal dari leluhur yang sama, suku atau daerah yang sama, memiliki bahasa dan adat-istiadat yang sama serta yang paling penting adalah dalam menjalani kehidupan bersama, mereka tidak membeda-bedakan agama, kelas sosial (kasta), dan tingkat ekonomi seseorang. Selain itu, Ain Ni Ain juga dapat dimaknai lebih sederhana, yaitu, satu tolong satu, satu bantu satu, satu susah semua susah, satu senang semua senang, dan satu punya semua punya (barang).

Pemaknaan sederhana dari falsafah hidup Ain Ni Ain, apabila dimaknai maka mengandung pengertian bahwa, orang Kei dalam kehidupan sehari-harinya harus saling tolong-menolong, saling membantu satu sama lain, apabila ada yang mengalami kesusahan maka yang lain juga turut merasakan kesusahan itu dengan cara memberi bantuan (Yelim), atau apabila ada yang merasakan kebahagiaan, maka yang lain juga turut merasakan kebahagiaan itu, misalnya ada acara perkawinan dari salah satu keluarga maka keluarga yang lain dapat datang untuk membantu bekerja membuat tenda atau memasak di dapur, atau apabila ada seseorang yang memiliki sesuatu barang, misalnya alat pertanian seperti pacul, maka dapat dipinjamkan kepada saudaranya yang membutuhkan.

Ain Ni Ain sebagai falsafah hidup orang kei, apabila dilihat dari pemaknaannya maka mengandung nilai-nilai sosial sangat tinggi. Nilai-nilai sosial mana yang kemudian menjadi dasar terwujudnya persaudaraan yang rukun di antara sesama orang Kei. Orang Kei dapat menjalani kehidupan bersama atau berkelompok, dimana saja mereka berada karena kuatnya pengaruh falsafah hidup yang mereka pedomani. Hal ini menunjukkan juga bahwa kehidupan bersama atau berkelompok yang selama ini dijalani oleh orang Kei tidak semata-mata disebabkan oleh ketersediaan lahan lokasi tempat tinggal yang terbatas atau strategis tetapi juga karena ada hubungan-hubungan sosial yang terjalin dengan baik 
sehingga memperkuat ikatan-ikatan persaudaraan serta rasa solidaritas sosial yang tinggi. Selain itu, Ain Ni Ain juga dapat dilihat sebagai salah satu bentuk modal sosial yang terdapat dalam kehidupan orang Kei. Hal ini karena, dalam Ain Ni Ain terdapat hubunganhubungan sosial yang terjalin dengan sangat baik. Bahkan terdapat juga norma-norma sosial yang secara tersirat terkandung dalam setiap hubungan-hubungan sosial yang terjalin di antara sesama orang Kei.

\section{Kesimpulan.}

Bertolak dari penjelasan-penjelasan sebelumnya maka beberapa pokok pikiran yang merupakan kesimpulan dapat disampaikan dalam penulisan ini. Pokok-pokok pikiran tersebut adalah sebagai berikut:

1. Orang Kei di Negeri Passo memang berbeda kelas sosial (kasta), tetapi perbedaan tersebut tidak menghalangi dan menjadi masalah bagi mereka dalam menjalani kehidupan bersama. Mereka hidup bersama walau dengan perbedaan yang ada.

2. Orang kei di Negeri Passo memiliki hubungan-hubungan sosial atau interaksi sosial yang sangat baik satu sama lain. Bentuk-bentuk interaksi sosial yang terdapat dalam kehidupan orang Kei, adalah seperti Yelim, Yelim Matmatan, dan Maren.

3. Orang Kei di Negeri Passo menjalani kehidupan bersama atau berkelompok. Walaupun mereka berbeda kelas sosial (kasta) tetapi dalam menjalani kehidupan, mereka selalu bersama atau berkelompok dan ini sudah menjadi kebiasaan hidup orang Kei di mana saja mereka ada.

4. Falsafah hidup orang Kei yaitu Ain Ni Ain, yang memiliki arti adanya rasa persaudaraan yang berasal dari leluhur yang sama, suku yang sama, bahasa yang sama, adat istiadat yang sama, dan tidak membeda-bedakan latar belakang agama, kelas sosial, ekonomi, dan lain-lain. Falsafah hidup Ain Ni Ain menjadi dasar yang kuat untuk terwujudnya rasa solidaritas sosial yang tinggi di antara sesama orang Kei.

\section{Daftar Pustaka}

Ajawaila J. W. 2005, “Dinamika Budaya Orang Maluku”, Dalam Maluku Menyambut Masa Depan. Lembaga Kebudayaan Daerah Maluku, Ambon.

Basrowi, 2005, “Pengantar Sosiologi”, Penerbit Ghalia Indonesia, Ciawi - Bogor. 
Fukuyama Francis, (2007),"TRUST”, Kebijakan Sosial dan Penciptaan Kemakmuran", Qalam, Yogjakarta.

Iskandar, 2009, “Metode Penelitian Kualitatif”, Gaung Persada, Jakarta.

Johnson Doyle Paul, “Teori Sosiologi Klasik dan Modern”, Diterjemahkan oleh Robert M. Z. Lawang (1988) PT. Gramedia, Jakarta.

Lawang M. Z. Robert, "Stratifikasi Sosial Di Cancar Manggarai Flores Barat Tahun 1950-an dan 1980-an", Penerbit FISIP UI, Depok.

Lawang Robert M. Z, 2004, "Kapital Sosial Dalam Perspektif Sosiologi Suatu Pengantar”, Fisip UI Press, Jakarta.

Miles, Matthew B dan Michael A Huberman, 2007. "Analisis Data Kualitatif", Universitas Indonesia, Jakarta.

Moleong, Lexy.J, 2005, “Metodologi Penelitian Kualitatif”, PT Remaja Rosdakarya, Bandung.

Nasikun, 2009, “Struktur Masyarakat Majemuk Indonesia”, Grafiti Perss, Yogyakarta.

Ohoitimur Yohanis, 1983, "Beberapa Sikap Hidup Orang Kei Antara Ketahanan Diri Dan Proses Perubahan”, Tesis Pineleng.

Pariela, T. D. 2008, "Damai di Tengah Konflik Maluku”, Preserved Social Capital sebagai Basis Survival Strategy, Program Pascasarjana Universitas Kristen Satya Wacana, Salatiga.

Rahail. J. P, 1993, "Larwul Ngabal Hukum Adat Kei”, Bertahan Menghadapi Arus Perubahan, Seri Pustaka Khasanah Budaya Lokal, Yayasan Sejati, Jakarta.

Ritzer George, 2012, “Teori Sosiologi, Dari Sosiologi Klasik Sampai Perkembangan Terakhir Postmodern”, Pustaka Pelajar, Yogyakarta.

Subagio, 2004, “Metode Penelitian Dalam Teori dan Praktek”, Rineka Cipta, Jakarta. Usman Sunyoto, 2008, “Pembangunan dan Pemberdayaan Masyarakat", Pustaka Pelajar, Yogyakarta. 